\title{
1. Introduction to women's entrepreneurship and culture: socio-cultural dynamics, role-influenced behaviors and constraint negotiation
}

\section{Ulrike Guelich, Amanda Bullough, Tatiana S. Manolova and Leon Schjoedt}

\section{INTRODUCTION}

Women's entrepreneurship is pivotal for both national economic development and societal advancement, as it provides employment opportunities and promotes self-reliance (Elam et al., 2019; UN Women, 2020; Venkatesh et al., 2017; World Bank, 2012). Gender equality and the empowerment of women are an effective way to combat poverty, hunger and disease and to stimulate sustainable economic development (Neimanis and Tortisyn, 2003). While it is generally recognized that the competitiveness of a country relies on the active involvement of women in education, business, politics, and research and development, existing gender stereotypical beliefs and practices, deeply ingrained in the socio-cultural context of a nation, can be a challenging constraint (Shukla and Arntzen, 2013). Indeeed, gender and culture dynamically interact, shaping gender role expectations and identities, and the economic and social environment in which women's entrepreneurship is embedded (Bullough et al., forthcoming).

According to the Global Entrepreneurship Monitor (GEM) Report on Women's Entrepreneurship 2018/2019 in 59 economies around the globe, around 231 million women were involved in entrepreneurial activities, either as start-ups or established business owners (Elam et al., 2019). Although women are increasingly engaged in entrepreneurship, their ownership still lags that of men (Pandey and Amezcua, 2020). While it is acknowledged that there is no single ideal context for entrepreneurship (Welter et al., 2017), socially supportive cultures enable both higher rates of entrepreneurial activity and the quality 
of women's entrepreneurship (Stephan and Uhlaner, 2010). While culture affects the rate and quality of women's entrepreneurial activities, women's entrepreneurial activities, in turn, shape societal norms, values and acceptance of women's business leadership roles. Succinctly put, culture shapes women's entrepreneurship and women's entrepreneurship shapes culture.

To better appreciate culture as an antecedent and a consequence of women's entrepreneurship, we begin by introducing the concept of culture. Culture may be viewed as a "rich complex of meanings, beliefs, practices, symbols, norms, and values prevalent among people in a society" (Schwartz, 2006, p. 138). It is manifested in artifacts, rituals and symbols and operates at multiple levels. At the deepest level, basic and invisible assumptions are taken for granted (Leung et al., 2005). Culture may also be considered as the "underlying system of values peculiar to a specific group or society" (Pinillos and Reyes, 2011, p. 25) and is one of six elements of an entrepreneurship ecosystem, besides finance, support systems, human capital, markets and policy (Walsh and Winsor, 2019). Culture operates at the organizational and at the small group (team) levels. In all, culture forms a context in which people function on a daily basis and, for entrepreneurs, a context that may facilitate or hinder entrepreneurs' actions in new venture creation and management.

Culture evolves over time on an ad hoc basis or by decision. If repeated actions or decisions are made by people who are in formal leadership positions, or are informal leaders and interpreted as desirable by a set of followers, those actions or decisions may become part of a culture. This means that the founders' personal values, espoused through actions and decisions, can mold the culture in the new venture over time (Ford et al., 2008; Selznick, 2011). As such, the espoused culture based on the personal values of the entrepreneur is instilled into the venture through a hierarchical process (Payne and Joyner, 2006). Cultural values are broad and encompassing, while entrepreneurship is a rather specific behavior. However, entrepreneurship constitutes value-based leadership if used by design (Stephan and Pathak, 2016). This shows that entrepreneurs' actions affect the culture of the new venture. The entrepreneurs' actions may also impact the culture beyond the new venture as direct and indirect stakeholders may consider the actions and decisions of the entrepreneur to be socially desirable.

Gender norms can be viewed as essential aspects of culture. Differences in women's entrepreneurship across societies and entrepreneurial activities can be explained by multifaceted explanations. Many gender-specific barriers and constraints relate to cultural values, norms and customs (Anambane and Adom, 2018; Baughn et al., 2006; Khandelwal and Sehgal, 2018). As just one example, large and voluminous images of a country's father figure, as seen in societies like North Korea and Thailand, inculcate a culture of respect for and value of a male figurehead. And yet, gender role expectations, gender egali- 
tarianism and the socio-cultural context in the ecosystem are under-researched cultural factors in women's entrepreneurship (Bullough et al., forthcoming). The goal of this book, therefore, is to foster a discussion among researchers, government agencies and related organizations on how culture enables or limits women's entrepreneurship.

We chose the topic for three reasons: first, discussions about the right ecosystems for women's entrepreneurship are gathering importance. Social and cultural norms are one of the important framework conditions for an entrepreneurial ecosystem, besides finance, government policies and programs, research and development transfer, physical and commercial infrastructure and market conditions (Elam et al., 2019). Private organizations who advise government policy makers encourage the development of stronger entrepreneurial ecosystems. Although business degrees alone are not the only pathway to business success for female entrepreneurs, institutions of higher education have increasingly integrated entrepreneurship education targeted at women into their strategic plans (Prill, 2019). Yet, gender inequalities remain deeply ingrained in every society, with women lacking access to decent work, facing occupational segregation and gender wage gaps (UN Women, 2020). In addition, in many cultures, women are often denied access to basic education and health care and are under-represented in political and economic decision-making processes (UN Women, 2020). Women across the globe are confronted with gendered cultural environments within diverse determinants of the entrepreneurial ecosystem that either foster or hinder the opportunity for women entrepreneurs and business owners to build and grow their businesses (Acs et al., 2016). Importantly, as the leaders of the Global Leadership and Organizational Behavior Effectiveness (GLOBE) project hypothesize, while the role of economic barriers in international business exchange have come down, cultural barriers for entrepreneurs and leaders may increase, because internationalization exposes the different values of the different cultures, making it more difficult to navigate across cultures (House et al., 2004).

Second, the roles and expectations, especially related to gender, vary significantly depending on the cultural context. The cultural context affects both male and female entrepreneurs by exerting pressures to behave in accordance with cultural norms (Welter and Smallbone, 2011). In general, cultural norms limit women's potential to pursue entrepreneurship more than men's (Masbout and Van Staveren, 2010). More specifically, in highly patriarchal, or conservative, cultures, two social realms exist: the outside and inside realms. The "outside realm" is where men are seen as breadwinners who work outside the home and control interactions between the family and the outside world (Schuler et al., 1996); while the "inside realm" is populated by women who depend on men to take care of them. In these cultures, women are often restricted to indoor activities; hence, they are hidden away from the outside world (Ali, 
2013; Ali et al., 2017). As a result, women's entrepreneurial or employment pursuits are limited, as the norms for women pertain to activities in the inside realm such as household management and child and elder caring. In these conservative cultures, women entrepreneurs are seen as non-conforming because they act against cultural norms by venturing out of the inside realm to pursue activities in the outside realm. By breaking into the outside realm to pursue new venture creation or business ownership, women entrepreneurs may be sanctioned by the cultural barriers such as lack of or limited family support, and limited access to funding and to networks (Tlaiss, 2015). In contrast, an egalitarian culture where men and women may share the activities in the inside and outside realms is conducive of women's entrepreneurship. According to the GLOBE study, societies with higher gender egalitarianism minimize role differences between genders (House et al., 2004). In such cultures women are welcomed, even encouraged, to pursue work outside the family domain. The benefits of the egalitarian culture, with its cultural norms of both men and women in the outside realm, cannot be understated. Extending GLOBE's work on gender egalitalitarianism by incorporating collectivism, and building on the notion of inside-outside realms, Bullough et al. (2017) demonstrated how women's entrepreneurship interacts with the family-level in-group differently, and more strongly, than it does with the societal-institutional level of collectivism. Women's participation in the outside realm is widely acknowledged as an important factor in economic growth (Brush et al., 2018; Bullough et al., 2017; De Bruin et al., 2006; Hechavarria et al., 2019).

Third, the concept of balancing norms associated with male-dominated family cultures and Western neoliberal values of entrepreneurship (Bruni et al., 2005) shows how economic and cultural contexts lead to struggles of individual women with these structural inequalities (e.g., Villares-Varela and Essers, 2019; Xheneti et al., 2019). As entrepreneurs tend to shape their living and working contexts, women also try to navigate the socio-cultural environment in order to engage in entrepreneurship.

With this volume, we not only contribute a gender perspective to cultural factors but also show how women in developing countries are able to carefully find a way around limitations. Governmental support to empower women to choose entrepreneurship as their career goal is not always successful and might lead to necessity-driven entrepreneurs within patriarchal cultural settings (Zhang et al., 2006). Women thus need to find their way within a cultural context to develop what they perceive as the best path to business success. In light of this, in this edited volume we sought chapters that fit within the overarching theme of women's entrepreneurship and culture with respect to the socio-cultural context, family roles and self-determination as influencers of women's entrepreneurship in different geographical and cultural conditions. 
Specifically, we sought chapters which offered valuable and novel perspectives on the contextual embeddedness of women's entrepreneurship and culture to create a better understanding of how, why and where gender plays a role in various cultural contexts. Our call for chapter proposals requested papers that covered the following factors:

- key cultural and societal settings, with a particular focus on women's entrepreneurship and culture;

- interactions between and among cultures and societies;

- cross-cultural similarities and differences;

- the impact of culture on women's entrepreneurship and the impact on culture on women's entrepreneurship.

In response to our call for chapter proposals, we received 36 submissions. After we reviewed all these submissions, 16 were solicited for full chapter contributions that were reviewed using a double-blind review process. Working with an editor and a set of reviewers, eight chapters met our expectations for inclusion in this book. Our final selection comprises both conceptual and empirical papers, employs a mixture of methodological approaches and adopts a range of perspectives on gender and culture. While each chapter offers its own unique viewpoint, collectively, the chapters offer a contemporary view of the socio-cultural embeddedness of women's entrepreneurship.

The eight chapters in this book fall into three main themes: (1) socio-cultural context as the base of women's entrepreneurship; (2) emancipation from traditional family roles; and (3) targeted policies and programs versus engrained women's rights leading to self-determination. These main themes are displayed in Figure 1.1. The figure also shows minor themes that overlap among the major context.

In the following three sections, we consider each of the main themes by introducing the topic and each of the chapters within the main theme with brief summaries of the authors' work.

\section{THE EFFECTS OF A SOCIETY'S CULTURE ON THE EMBEDDEDNESS OF WOMEN'S ENTREPRENEURSHIP}

Society and culture are highly influential contextual factors for women's entrepreneurship (Bastian et al., 2019). Examining culture across national boundaries is often complicated because of differences among values, languages and meanings that may cause ambiguity (Gunnell, 2016). Culture comprises the values that a society is built upon. This indicates that a cross-cultural entrepreneurship study is challenged by the effects of culture on meanings and values as seen in some cultures where entrepreneurship is seen as a last resort option 


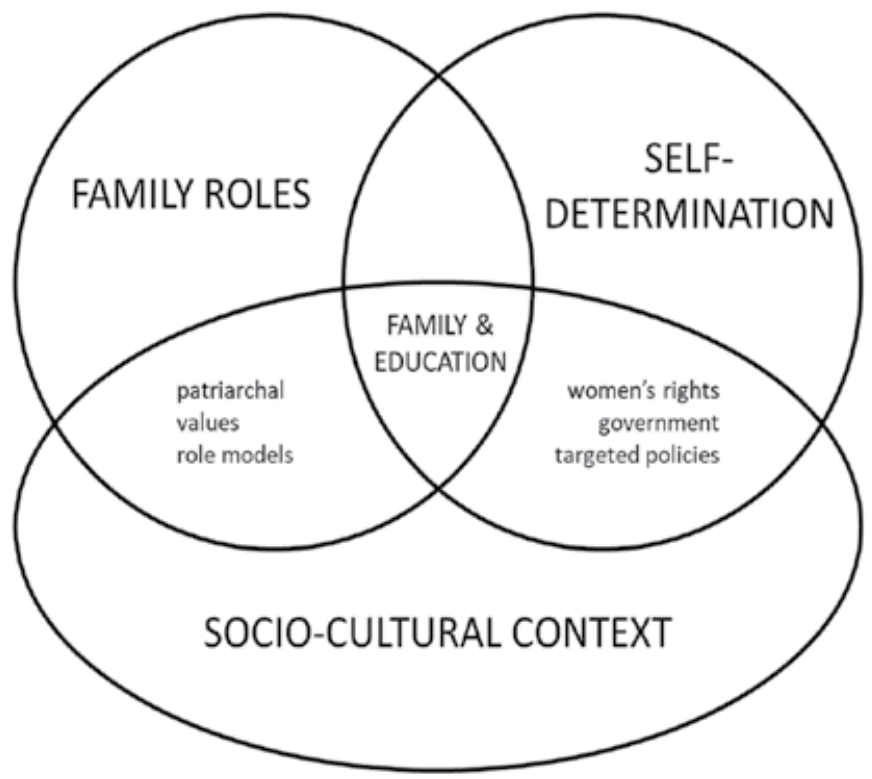

Figure 1.1 The interplay of socio-cultural context with family roles and self-determination

$$
\begin{aligned}
& \text { collectivism outside barriers } \\
& \text { power distance globe } \\
& \text { socio-cultural context } \\
& \text { religion values } \\
& \text { language beliefs hofstede }
\end{aligned}
$$

Figure 1.2 Socio-cultural context 
for employment while in others it may be seen as a revered opportunity for employment.

Research on women's entrepreneurship in developing countries, specifically those with patriarchal societies, identifies barriers, struggles and difficulties for women entrepreneurs (e.g. Al-Dajani and Marlow, 2013; Itani et al., 2011; Naguib and Jamali, 2015). Despite this research, there are a multitude of research opportunities to provide a more nuanced and deeper understanding of socio-cultural influence on women entrepreneurs. This may be within and between socio-cultural contexts.

In Chapters 2 and 3, under the theme "The effects of a society's culture on the embeddedness of women's entrepreneurship", Bastian, Metcalfe and Hill and Au, Nourin and Ahmed utilize the two large research studies on culture and entrepreneurship: Geert Hofstede's six cultural dimensions and the Global Leadership and Organizational Behavior Effectiveness (GLOBE) study. In Chapters 2 and 4, Bastian et al. and Torres and Augusto respectively also explore the context of patriarchal societies and their impact on women entrepreneurs, questioning if women entrepreneurs might be able to break the glass ceiling in a patriarchal society context.

The chapters utilizing Hofstede's cultural dimensions investigate the influence of the six dimensions on patriarchal societies and regional differences and institutional collectivism in comparison to in-group collectivism, displaying the effects of a society's culture on its values and how these values then relate to actual behavior (Hofstede 2015).

In Chapter 2, Bastian, Metcalfe and Hill investigate the MENA (Middle East and Northern Africa) region, where many countries exhibit some of the largest gender inequalities worldwide (World Economic Forum, 2018). This chapter compares the differences in entrepreneurship for both genders between the Mediterranean geographic territory and the Arab Gulf territory and explores how gendered cultural and governance factors contribute to different entrepreneurial outcomes and experiences in the region.

Bastian et al. categorized 15 countries of the MENA region into two "blocks"and highlight substantial gendered differences in entrepreneurial activities within Mediterranean countries and Gulf countries over the last decade, with the Gulf countries in MENA having achieved near gender parity in entrepreneurship by 2018, fueled, amongst other things, by gender quotas implemented by the governments. In general, men in the largely patriarchal MENA societies (Hofstede, 1992) are regarded as decisive, whereas women are seen as intuitive and relationship-focused (Omair, 2008), thus less powerful and influential (Zamberi Ahmad, 2011). One focus of Bastian et al. is therefore related to work-family balance as one of the greatest challenges for women entrepreneurs across the MENA region (e.g. Erogul and McCrohan, 2008), constraining women entrepreneurs, who are expected to combine 
family obligations and responsibilities in their roles as mother, daughter or daughter-in-law with their entrepreneurial endeavors.

Bangladesh (Chapter 3) with its strong patriarchal societal orientation and a Muslim majority of 90 percent of the population, determines the context of this chapter, with $\mathrm{Au}$, Nourin and Ahmed exploring the role of agency on women entrepreneurs, embedded within the three sections of gender, religion and socio-economic class. Au et al. discuss how and if entrepreneurship can help women in Bangladesh build agency and if women can act as agents for change. The findings contrast sharply with the idealized and romanticized view of entrepreneurship as the "Holy Grail of elevation and emancipation" (Verduijn and Essers, 2013, p. 100) as entrepreneurial activities of women are often only possible at high personal costs, specifically with regard to psychological and physical well-being. Whereas many studies focus on women entrepreneurs' success stories and see them not restricted by socio-cultural context factors (Khan et al., 2007; Weik, 2011), Au et al. point out the risks and costs for the individual women, ingrained in a societal context that limits their entrepreneurial activities.

In addition to utilizing the GLOBE study, Torres and Augusto in Chapter 4 also draw on World Bank data and study the 20 countries of Argentina, Australia, Austria, Czech Republic, Denmark, Finland, France, Greece, Hungary, Ireland, Italy, Japan, the Netherlands, New Zealand, Poland, Portugal, Slovenia, Spain, Sweden and the United States. To shed light on the role of self-protective leadership ideals, Torres and Augusto identify combinations of cultural practices and culturally-endorsed leadership ideals, leading to higher levels of women's self-employment. By using qualitative comparative analysis, the authors point out that different combinations of factors such as uncertainty avoidance, institutional and in-group collectivism and self-protective leadership ideals can lead to different outcomes, depending on the cultural context. In addition, configurations of different combinations of factors contribute to clarify the role of collectivism with regard to women's entrepreneurship, suggesting that the importance of collectivism is overestimated because its presence or absence appeared to be irrelevant for the entrepreneurial activities of women entrepreneurs.

\section{WOMEN'S EMANCIPATION FROM TRADITIONAL FAMILY ROLES}

Theme 2 narrows the contextualized view of women's entrepreneurship to entrepreneurial activity in a particular context (Brush et al., 2009; 2017; Welter, 2011), that of the family. In many emerging economies, women entrepreneurs tend to operate their businesses as part of the informal economy (ILO, 2009; UNESCAP 2017). These businesses are also often smaller, grow 


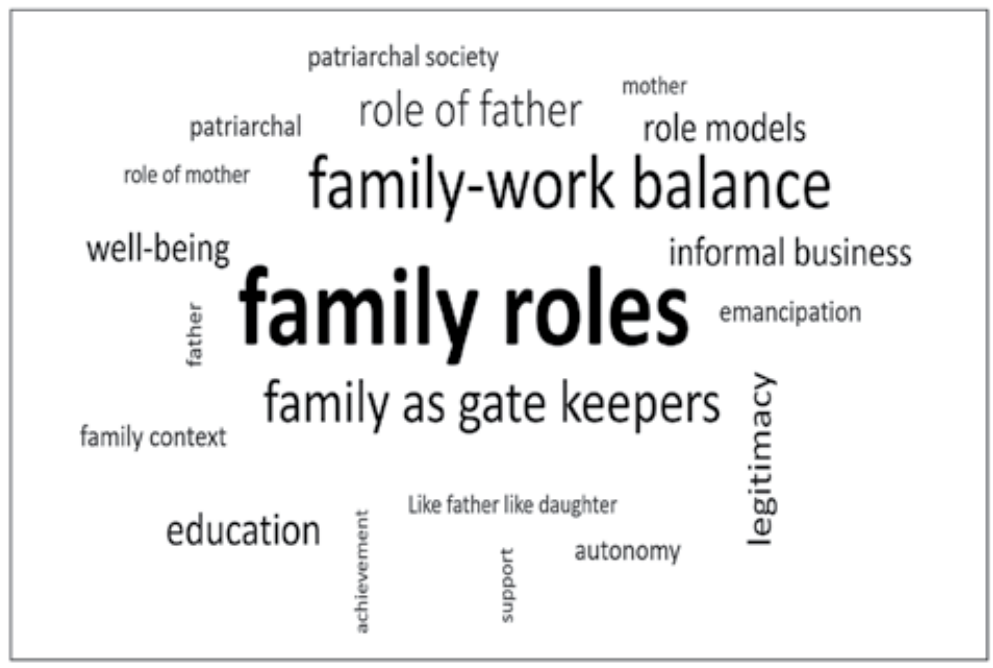

Figure 1.3 Family-work balance

more slowly and are less profitable (Bardasi et al., 2011; Hallward-Driemeier, 2013). Gender norms and societal values influence what a woman can do or cannot do and thus shape women's entrepreneurial activities (Jamali, 2009). Depending on how context and entrepreneurship intertwine, they influence entrepreneurship dynamics and either enable or constrain particular role-influenced behaviors (Markowska and Lopez-Vega, 2018). Family context consigns women and men to cultural norms and values (Bullough et al., 2017; Nelson and Constantinidis, 2017) and can be seen as the closest and possibly strongest network. Thus, new venture creation is influenced by an individual's family-related roles and responsibilities (Jennings and Brush, 2013).

In Chapters 5 and 6, Markowska and Tesfaye Abebe, and Irene, Murithi, Frank and Mandawa-Bray, respectively, display the importance of women entrepreneurship and their role for the economic development of African countries, looking at interfaces between women entrepreneurship, economic empowerment and breaking free from familial roles, thus emancipating from their situations. Both chapters highlight the importance of non-economic factors that could lead to autonomy and freedom for women entrepreneurship, increasing feelings of motivation and personal achievement in women. In Chapter 7, Banu, Baral, Agarwal and Rastogi add an Asian component to 
the same context where a patriarchal society and caste systems in India limit women's entry into entrepreneurship without familial support.

Specifically, Markowska and Tesfaye Abebe examine which cultural constraints limit the attractiveness of entrepreneurship as a career choice for well-educated women in Ethiopia, where gender inequality and female subordination are largely present despite government efforts to encourage more women into entrepreneurship (Amine and Staub, 2009; Kalantaridis and Fletcher, 2012), and how to overcome these cultural challenges. Markowska and Tesfaye Abebe identify three major constraints for Ethiopian women to legitimate their entrepreneurial endeavors: (1) women entrepreneurs experienced problems convincing family and friends that entrepreneurship was a legitimate career path for them, especially as they were well educated: while families can accept the necessity for informal entrepreneurship among poor and less well-educated women, they disapprove of entrepreneurship by educated women; (2) families objected to the type of business; and (3) women were censured for prioritizing business over the role of mother.

In Chapter 6, Irene, Murithi, Frank and Mandawa-Bray present entrepreneurship as a socio-economic dilemma between the traditional role of women in South Africa and the interface of women entrepreneurship, economic empowerment and emancipation, analyzing interviews with 152 South African women entrepreneurs. The findings of Irene et al. demonstrate the resilience of women entrepreneurs, choosing entrepreneurship not only as a way out of poverty but also as a way out of a life of subordination, dependence on men and obscurity by family. Thus, entrepreneurship is able to eliminate perceived barriers for women, especially barriers that hinder them from fully participating in economic and social activities. As a result, non-economic factors such as autonomy and freedom in entrepreneurial activities help women feel motivation and achievement.

In Chapter 7, Banu, Baral, Agarwal and Rastogi investigate the impact of society and culture on the decision of women to enter entrepreneurship and on their business performance through interviews with 20 female Indian small business entrepreneurs. The combination of family, community, cultural and religious norms of India have intentionally or unintentionally influenced Indian society, limiting a girl's literacy, education and occupational mobility (Senapati and Ojha, 2019), contributing to a female to male entrepreneurship ratio of 0.7 , with only seven women entrepreneurs compared to ten men entrepreneurs (Bosma and Kelley, 2019). Banu, Baral, Agarwal and Rastogi applied Geert Hofstede's cultural dimensions to the Indian context to develop an in-depth understanding of women's career choices towards entrepreneurship. Culture was found to be highly influential for business growth and success of women entrepreneurs in India, especially since male family support is needed for women to start and run their businesses due to the strong family orientation 
of the Indian culture, a pervasive gender inequality, the dominance of masculinity, and widened power distance in the society.

\section{CULTURE AND SELF-DETERMINATION IN WOMEN'S ENTREPRENEURSHIP}

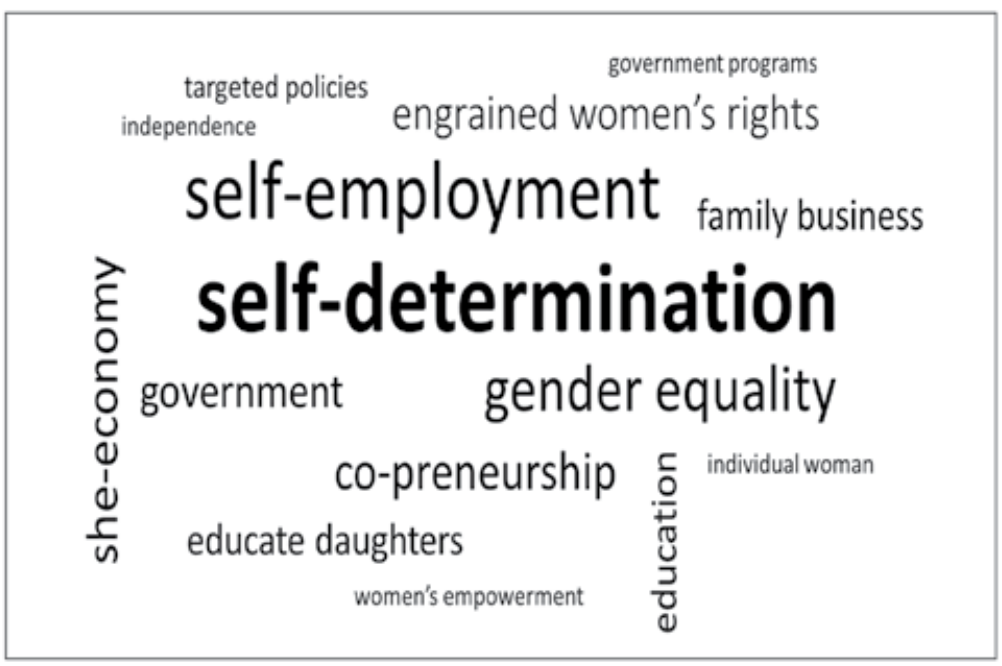

Figure $1.4 \quad$ Self-determination

The concept of balancing norms associated with male-dominated family cultures and Western neoliberal values of entrepreneurship shows how economic and cultural contexts lead to struggles of individual women with structural inequalities. This work-life imbalance creates barriers for women starting and running businesses. Thus, women have found ways to combine work and personal lives (Ruderman et al., 2002). Women in male-dominated family cultures might decide to choose self-determination to enter entrepreneurship, be it in negotiating within the cultural context or navigating limitations by finding the least offensive approach within cultural constraints. On the other hand, also balancing work and personal responsibilities, family businesses are the most prevalent form of businesses in the world (Lien et al., 2016; Oudah et al., 2018), accounting for more than half of the GDP, 60 percent of new employment, and 65 percent of wages paid (Pieper et al., 2013). A specific form, but not a new phenomenon, of family businesses is entrepreneurial couples, firms owned and managed by a couple (Othman et al., 2016). Their 
number is increasing at a higher rate than other types of businesses (Othman et al., 2016; Wu et al., 2010), with advantages for the economies because of higher productivity (Dahl et al., 2015); however, on the down side, few of them survive in the long term (Nicholson, 2008).

To balance the different norms and limitations of both purely women-led or co-preneurial businesses, Zhang and Jurik (Chapter 8) and Arasti, Sadeghi and Saeedian (Chapter 9) suggest that policies are needed to overcome the socio-cultural challenges of women to increase the feasibility of creating women's entrepreneurship in different formations. Both chapters investigate women entrepreneurship in an Asian context. In Chapter 8, Zhang and Jurik explore how women in patriarchal China simultaneously construct businesses and gender in the context of country and family. Supported by the Chinese government's promotion for women's self-employment, the term "she economy" evolved, acknowledging women's contributions to economic development through both self-employment and consumption (Ren, 2019). While most women entrepreneurs in China run necessity-driven microenterprises with little to no employees and limited start-up capital (Chan and Lin, 2014; Wang, 2017), younger, college-educated women prioritized work and self-employment over family, leading to postponing marriage and motherhood. The authors suggest that the Chinese government's interest in promoting women's entrepreneurship develops from the strategy to make use of women entrepreneurs' productive potential for economic growth rather than promoting gender equality.

In Chapter 9, Arasti, Sadeghi and Saeedian provide a study on co-preneurship as a gendered process in Iran, where prevailing gender ideologies are rooted in social norms and a patriarchal culture. The authors investigate the socio-cultural context of women in co-preneurial businesses by interviewing 14 female heads of small early-stage businesses in the service sector in Tehran, Iran and applying institutional theory. The findings extend existing knowledge about family businesses by shedding light on the under-studied field of co-preneurial businesses in the context of a culture where women's entrepreneurship is constrained by societal norms which prefer women to work with their family in the workplace rather than with external people.

With these considerations of the eight chapters that constitute the remainder of this book complete, we turn to how the chapters in combination, that is, this book as a whole provide new insights in women's entrepreneurship and culture to advance the literature on women's entrepreneurship.

\section{CONCLUDING COMMENTS}

Our objective with this edited volume was to assemble contributions that offer valuable and novel perspectives on the socio-cultural embeddedness of 
women's entrepreneurship in order to better understand the interplay between women's entrepreneurship and culture. Collectively, the studies included in this volume provide a rich portrayal of the multi-faceted interactions between gender and culture in different economic, social and institutional contexts around the world. While cultural norms and espoused traditions still present numerous hurdles to women's entrepreneurial initiatives, it is also evident that women's entrepreneurial agency can lead to wider social acceptance and support for women's economic participation and leadership. Through self-determination, which often challenges the traditional family roles, women entrepreneurs can shape and structure the socio-cultural context and thus be a powerful force for change.

With the studies included in this volume, we make a substantial contribution to advancing knowledge about women's entrepreneurship and culture. Future work can provide additional insights into this complex interaction through several avenues of research with regard to the topics.

The studies display a significant heterogeneity in cultural contexts. More detailed research has to target how women's entrepreneurship is, or is not, embedded in the political and institutional environment. Gender parity in entrepreneurship in certain cultural contexts cannot be compared to those in others, as state-promoted gender equality, for example in patriarchal countries, might result in different entrepreneurial outcomes for women than a gender parity embedded in the day-to-day culture of a country.

As the studies reveal, constraints of certain women entrepreneurs stem from the interplay of gender, religion and social class and go beyond merely economic pressures. Thus, more insights are needed to understand the social struggles of women entrepreneurs for legitimized acceptance and gender equality to be able to build on opportunities in entrepreneurship. Future studies should try to shed light on how policy-makers, aiming to promote and thus embed women's entrepreneurship into their cultures, can do so by changing societal culture as cultural practices are difficult to change. In this regard, research exploring different dimensions and norms of culture and their impact on changing the beliefs about equality in women's entrepreneurship could contribute to quality entrepreneurship not only on a communal, regional or country level but also in rural versus urban settings and in the family context. In addition, future studies could investigate how a more sensitive government influence towards the socio-cultural dimensions of women's experiences could lead to successful self-determination of women entrepreneurs, instead of necessity-driven entrepreneurship.

As many studies have local or regional perspectives, and thus cannot be generalized even across a single country, further studies of women's entrepreneurship across different patriarchal societies or regions could deliver 
a larger picture and contribute towards more generalizable entrepreneurship theory-building of women's entrepreneurship and culture.

In conclusion, insights on the influencers of the socio-cultural context, of traditional family roles and self-determination on women's entrepreneurship, can lead to a better understanding of necessary measures, leading not only to higher rates of women's entrepreneurship but also to increased quality of their enterprises. A unified effort for initiatives supporting women in different cultural contexts, combined with targeted policies and cultural education of communities, could help remove barriers to an increase of women's representation in business. There are still significant gaps to be filled in this area. We hope that with the studies included in this volume, we give an overview of some less-researched countries and research fields to enhance the knowledge about women's entrepreneurship and culture and their embeddedness in the socio-cultural context.

\section{REFERENCES}

Acs, Z., T. Åstebro, D. Audretsch and D.T. Robinson (2016), 'Public policy to promote entrepreneurship: A call to arms'. Small Business Economics, 47 (1), 35-51.

Al-Dajani, H. and S. Marlow (2013), 'Empowerment and entrepreneurship: A theoretical framework'. International Journal of Entrepreneurial Behavior \& Research, 19 (5), 503-24.

Ali, F. (2013), 'A multi-level perspective on equal employment opportunity for women in Pakistan'. Equality, Diversity and Inclusion: An International Journal, 32 (3), 289-309.

Ali, F., A. Malik, V. Pereira and A.A. Ariss (2017), 'A relational understanding of work-life balance of Muslim migrant women in the West: Future research agenda'. International Journal of Human Resource Management, 28 (8), 1163-81.

Amine, L.S. and K.M. Staub (2009), 'Women entrepreneurs in sub-Saharan Africa: An institutional theory analysis from a social marketing point of view'. Entrepreneurship \& Regional Development, 21 (2), 183-211.

Bardasi, E., S. Sabarwal and K. Terrell (2011), 'How do female entrepreneurs perform? Evidence from three developing regions'. Small Business Economics, 37 (4), 417.

Bastian, B.L., B.D. Metcalfe and M.R. Zali (2019), 'Gender inequality: Entrepreneurship development in the MENA region', Sustainability, 11 (22), 6472.

Bosma, N. and D. Kelly (2019), 'The Global Entrepreneurship Monitor 2018/2019 Global Report', accessed 5 August 2020 at https://www.gemconsortium.org/report/ gem-2018-2019-global-report.

Bruni, A., S. Gherardi and B. Poggio (2005), Gender and Entrepreneurship: An Ethnographical Approach, New York, NY: Routledge.

Brush, C., A. de Bruin and F. Welter (2009), ‘A gender-aware framework for women's entrepreneurship'. International Journal of Gender and Entrepreneurship, 1 (1), $8-24$.

Brush, C., A. Ali, D. Kelley and P. Greene (2017), 'The influence of human capital factors and context on women's entrepreneurship: Which matters more?'. Journal of Business Venturing Insights, 8, 105-13. 
Brush, C., L.F. Edelman, T. Manolova and F. Welter (2018), 'A gendered look at entrepreneurship ecosystems'. Small Business Economics, 52 (3), 393-408.

Bullough, A., M. Renko and D. Abdelzaher (2017), 'Women's business ownership: Operating within the context of institutional and in-group collectivism'. Journal of Management, 43 (7), 2037-64.

Bullough, A., U. Guelich, T.S. Manolova and L. Schjoedt (forthcoming), 'Women's entrepreneurship and culture: Gender role expectations and identities, societal culture, and the entrepreneurial environment'. Small Business Economics Journal.

Chan, S. and J. Lin (2014), 'Financing of micro and small enterprises in China: An exploratory study'. Structural Change, 22, 431-46.

Dahl, M.S., M. Van Praag and P. Thompson (2015), 'Entrepreneurial couples'. In Academy of Management Proceedings (Vol. 2015, No. 1, p. 14776). Briarcliff Manor, NY: Academy of Management.

De Bruin, A., C.G. Brush and F. Welter (2006), 'Introduction to the special issue: Towards building cumulative knowledge on women's entrepreneurship'. Entrepreneurship Theory and Practice, 30 (5), 585-93.

Elam, A.B., C.G. Brush, P.G. Greene, B. Baumer, M. Dean and R. Heavlow (2019), 'Global Entrepreneurship Monitor 2018/2019 Women's Entrepreneurship Report'. Babson College, Smith College, and the Global Entrepreneurship Research Association (GERA). Accessed 23 February 2020 at https://www.gemconsortium .org/report/gem-20182019-womens-entrepreneurship-report.

Erogul, M.S. and D. McCrohan (2008), 'Preliminary investigation of Emirati women entrepreneurs in the UAE'. African Journal of Business Management, 2 (10), $177-85$.

Ford, J.D., L.W. Ford and A. D'Amelio (2008), 'Resistance to change: The rest of the story'. Academy of Management Review, 33 (2), 362-77.

Gunnell, M. (2016), 'A comparison of the GLOBE and Geert Hofstede findings and their implications for global business leaders'. Accessed 3 November 2020 at https:// www.linkedin.com/pulse/comparison-findings-globe-geert-hostede-implications -global-gunnell/.

Hallward-Driemeier, M. (2013), Enterprising Women: Expanding Economic Opportunities in Africa. Washington, DC: World Bank Publications.

Hechavarria, D., A. Bullough, C. Brush and L. Edelman (2019), 'High growth women's entrepreneurship: Fueling social and economic development'. Journal of Small Business Management, 57 (1), 5-13.

Hofstede, G. (1992), 'Cultural dimensions in people management: The socialization perspective'. In V. Pucik, N.M. Tichy and C.K. Barnett (eds), Globalizing Management: Creating and Leading the Competitive Organization, New York, NY: Wiley \& Sons.

Hofstede, G. (2015), 'Culture's causes: The next challenge'. Cross Cultural Management: An International Journal, 22 (4), 545-69.

House, R.J., P.J. Hanges, M. Javidan, P. Dorfman and V. Gupta (2004), Culture, Leadership, and Organizations: The GLOBE Study of 62 Societies. Thousand Oaks, CA: Sage.

ILO (2009), 'The informal economy in Africa: Promoting transition to formality: Challenges and strategies'. Geneva: International Labour Organisation.

Itani, H., Y.M. Sidani and I. Baalbaki (2011), 'United Arab Emirates female entrepreneurs: Motivations and frustrations'. Equality, Diversity and Inclusion: An International Journal, 30 (5), 409-24. 
Jamali, D. (2009), 'Constraints and opportunities facing women entrepreneurs in developing countries'. Gender in Management: An International Journal, 24 (4), 232-51.

Jennings, J.E. and C.G. Brush (2013), 'Research on women entrepreneurs: Challenges to (and from) the broader entrepreneurship literature?'. Academy of Management Annals, 7 (1), 663-715.

Kalantaridis, C. and D. Fletcher (2012), 'Entrepreneurship and institutional change: A research agenda'. Entrepreneurship \& Regional Development, 24 (3-4), 199-214.

Khan, F.R., K.A. Munir and H. Willmott (2007), 'A dark side of institutional entrepreneurship: Soccer balls, child labour and postcolonial impoverishment'. Organization Studies, 28 (7), 1055-77.

Leung, K., R.S. Bhagat, N.R. Buchan, M. Erez and C.B. Gibson (2005), 'Culture and international business: Recent advances and their implications for future research'. Journal of International Business Studies, 36 (4), 357-78.

Lien, Y.C., C.C. Teng and S. Li (2016), 'Institutional reforms and the effects of family control on corporate governance'. Family Business Review, 29 (2), 174-88.

Markowska, M. and H. Lopez-Vega (2018), 'Entrepreneurial storying: Winepreneurs as crafters of regional identity stories'. The International Journal of Entrepreneurship and Innovation, 19 (4), 282-97.

Masbout, R. and I. Van Staveren (2010), 'Disentangling bargaining power from individual and household level to institutions: Evidence on women's position in Ethiopia'. World Development, 38 (5), 783-96.

Naguib, R. and D. Jamali (2015), 'Female entrepreneurship in the UAE: A multi-level integrative lens'. Gender in Management: An International Journal, 30 (2), 135-61.

Neimanis, A. and A. Tortisyn (2003), 'NHDR occasional paper 2: Gender thematic guidance note'. Accessed 5 July 2020 at http://hdr.undp.org/sites/default/files/nhdr gender_gn.pdf.

Nelson, T. and C. Constantinidis (2017), 'Sex and gender in family business succession research: A review and forward agenda from a social construction perspective'. Family Business Review, 30 (3), 219-41.

Nicholson, N. (2008), 'Evolutionary psychology and family business: A new synthesis for theory, research, and practice'. Family Business Review, 21 (1), 103-18.

Omair, K. (2008), 'Women in management in the Arab context'. Education, Business and Society: Contemporary Middle Eastern Issues, 1 (2), 107-23.

Othman, N., S. Mohamed and S. Suradi (2016), 'Motivating factors of couple involvement in copreneurship businesses in Malaysia'. International Journal of Social, Behavioral, Educational, Economic, Business and Industrial Engineering, 10 (1), 256-9.

Oudah, M., F. Jabeen and C. Dixon (2018), 'Determinants linked to family business sustainability in the UAE: An AHP approach'. Sustainability, 10 (1), 246.

Pandey, S. and A.S. Amezcua (2020), 'Women's business ownership and women's entrepreneurship through the lens of US federal policies'. Small Business Economics, 54 (4), 1123-52.

Payne, D. and B.E. Joyner (2006), 'Successful U.S. entrepreneurs: Identifying ethical decision-making and social responsibility behaviors'. Journal of Business Ethics, 65, 203-17.

Pieper, T.M., J.H. Astrachan and G.E. Manners (2013), 'Conflict in family business: Common metaphors and suggestions for intervention'. Family Relations, 62 (3), 490-500. 
Pinillos, M.J. and L. Reyes (2011), 'Relationship between individualist collectivist culture and entrepreneurial activity: Evidence from Global Entrepreneurship Monitor data'. Small Business Economics, 37 (1), 23-37.

Prill, O. (2019), 'Soft skills and university support foster female entrepreneurs'. Accessed 20 October 2020 at https://www.timeshighereducation.com/blog/soft -skills-and-university-support-foster-female-entrepreneurs.

Ren, X. (2019), 'She economy makes rapid strides', China Daily. Accessed 1 November 2019 at www.chinadaily.com.cn/a/201903/08/WS5c81a82da3106c 65c34ed6bf.html.

Ruderman, M.N., P.J. Ohlott, K. Panzer and S.N. King (2002), 'Benefits for multiple roles for managerial women'. Academy of Management Journal, 45 (2), 369-86.

Schuler, S.R., S.M. Hashemi, A.P. Riley and S. Akhter (1996), 'Credit programs, patriarchy and men's violence against women in rural Bangladesh'. Social Science \& Medicine, 43 (12), 1729-42.

Schwartz, S.H. (2006), 'A theory of cultural value orientations: Explication and applications'. Comparative Sociology, 5 (2), 137-82.

Selznick, P. (2011), Leadership in Administration: A Sociological Interpretation. New Orleans, LA: Quid Pro Books.

Senapati, A.K. and K. Ojha (2019), 'Socio-economic empowerment of women through micro-entrepreneurship: Evidence from Odisha, India'. International Journal of Rural Management, 15 (2), 159-84.

Shukla, M. and A.B. Arntzen (2013), 'Gender diversity in management and leadership: A new competitive advantage?'. Paper presented at the International Conference on Management, Leadership and Governance ICMLG 2013, Bangkok University, 8 February.

Stephan, U. and S. Pathak (2016), 'Beyond cultural values? Cultural leadership ideals and entrepreneurship'. Journal of Business Venturing, 31 (5), 505-23.

Stephan, U. and L.M. Uhlaner (2010), 'Performance-based vs socially supportive culture: A cross-national study of descriptive norms and entrepreneurship'. Journal of International Business Studies, 41 (8), 1347-64.

Tlaiss, H.A. (2015), 'How Islamic business ethics impact women entrepreneurs: Insights from four Arab Middle Eastern countries'. Journal of Business Ethics, 129 (4), 859-77.

UNESCAP (2017), 'Fostering women's entrepreneurship in ASEAN: Transforming prospects, transforming societies'. Bangkok: ESCAP.

UN Women (2020), 'United Nations entity for gender equality and the empowerment of women'. Accessed 15 October 2020 at https://www.un.org/womenwatch/daw/ daw/index.html.

Venkatesh, V., J.D.Shaw, T.A. Sykes, S.F. Wamba and M.W. Macharia (2017), 'Networks, technology, and entrepreneurship: A field quasi-experiment among women in rural India'. Academy of Management Journal, 60, 1709-40.

Verduijn, K. and C. Essers (2013), 'Questioning dominant entrepreneurship assumptions: The case of female ethnic minority entrepreneurs'. Entrepreneurship \& Regional Development, 25 (7-8), 612-30.

Villares-Varela, M. and C. Essers (2019), 'Women in the migrant economy: A positional approach to contextualize gendered transnational trajectories'. Entrepreneurship \& Regional Development, 31 (3-4), 213-25.

Walsh, J. and B. Winsor (2019), 'Socio-cultural barriers to developing a regional entrepreneurial ecosystem'. Journal of Enterprising Communities: People and Places in the Global Economy, 13 (3), 263-82. 
Wang, D. (2017), 'Chinese women's fortune report of 2017'. Accessed 16 April 2020 at http://i8.hexunimg.cn/hxsps/2017/whitepaper.pdf.

Weik, E. (2011), 'Institutional entrepreneurship and agency'. Journal for the Theory of Social Behaviour, 41 (4), 466-81.

Welter, F. (2011), 'Contextualising entrepreneurship: Conceptual challenges and ways forward'. Entrepreneurship Theory and Practice, 35 (1), 165-84.

Welter, F. and D. Smallbone (2011), 'Institutional perspectives on entrepreneurial behavior in challenging environments'. Journal of Small Business Management, 49 (1), 107-25.

Welter, F., T. Baker, D.B. Audretsch and W.B. Gartner (2017), 'Everyday entrepreneurship - A call for entrepreneurship research to embrace entrepreneurial diversity'. Entrepreneurship Theory and Practice, 41 (3), 311-21.

World Bank (2012), 'World Development Report 2012: Gender equality and development'. Accessed 1 July 2019 at https://openknowledge.worldbank.org/handle/ $10986 / 4391$.

World Economic Forum (WEF) (2018), The Global Gender Gap Report 2018. Accessed 28 July 2020 at http://www3.weforum.org/docs/WEF_GGGR_2018.pdf.

Wu, M., C.C. Chang and W.L. Zhuang (2010), 'Relationships of work-family conflict with business and marriage outcomes in Taiwanese copreneurial women'. The International Journal of Human Resource Management, 21 (5), 742-53.

Xheneti, M., S. Karki and A. Madden (2019), 'Negotiating business and family demands within a patriarchal society: The case of women entrepreneurs in the Nepalese context'. Entrepreneurship \& Regional Development, 31 (3-4), 259-87.

Zamberi Ahmad, S. (2011), 'Evidence of the characteristics of women entrepreneurs in the Kingdom of Saudi Arabia: An empirical investigation'. International Journal of Gender and Entrepreneurship, 3 (2), 123-43.

Zhang, J., L.X. Zhang, S. Rozelle and S. Boucher (2006), 'Self-employment with Chinese-characteristics: The forgotten engine of rural China's growth'. Contemporary Economic Policy, 24 (3), 446-58. 